De Jure: Jurnal Hukum dan Syar'iah

Vol. 11, No. 2, 2019, h. 76-89

ISSN (Print): 2085-1618, ISSN (Online): 2528-1658

DOI: http://dx.doi.org/10.18860/j-fsh.v11i2.6614

Available online at http://ejournal.uin-malang.ac.id/index.php/syariah

\title{
The Legality of Mandatory Testaments for an Adopted Child in the Perspective of 'Urf Principle
}

\author{
Munadi Usman \\ IAIN Lhokseumawe Aceh, Indonesia \\ munadiusman83@gmail.com
}

\begin{abstract}
:
Islamic Law Compilation (ILC) in article 209 contains provisions on the mandatory testaments of adopted children. Some legal experts in Indonesia have denied these provisions as they have no clear legal basis in Syariah or Islamic jurisprudence. This research aims to review the provision of mandatory testaments using the 'urf principle. This research is a legal normative study using conceptual and statute approaches. The result of this study shows that the tradition ('urf) in the form of giving assets to children applies in Indonesian society, even though practically there are still differences between one region to another according to their respective customary law systems. The 'urf can be taken into consideration to institutionalize the mandatory testaments for adopted children providing that it can be proven to be a valid 'urf.

Kompilasi Hukum Islam (KHI) dalam pasal 209 berisi ketentuan tentang wasiat wajib anak adopsi. Beberapa ahli hukum di Indonesia telah menolak ketentuan ini karena mereka tidak memiliki dasar hukum yang jelas dalam yurisprudensi Syariah atau Islam. Penelitian ini bertujuan untuk meninjau ketentuan perjanjian wajib menggunakan prinsip 'urf. Penelitian ini merupakan penelitian normatif hukum dengan menggunakan pendekatan konseptual dan statuta. Hasil penelitian ini menunjukkan bahwa tradisi ('urf) dalam bentuk memberikan aset kepada anak-anak berlaku di masyarakat Indonesia, meskipun secara praktis masih ada perbedaan antara satu daerah dengan daerah lain sesuai dengan sistem hukum adat mereka masing-masing. 'Urf dapat dipertimbangkan untuk melembagakan wasiat wajib untuk anak-anak adopsi asalkan itu dapat dibuktikan sebagai 'urf yang shahih.
\end{abstract}

Keywords: mandatory testaments; adopted child; 'urf.

\section{Introduction}


Islamic Law Compilation (ILC) is a formulation of the Islamic law compiled by Indonesian jurists to become material civil law for Indonesian Muslims in resolving various cases in the field of marriage, inheritance, and endowments based on Islamic law. The formulation of ILC refers to various Islamic jurisprudence literature from four schools and civil law laws that apply in several Muslim countries such as Egypt, Morocco, Tunisia, Turkey, and others. The collaboration of various kinds of literature and laws then produced a book of Islamic Law Compilation dedicated to Indonesian Jurisprudence.

A study conducted by Hikmatullah on ILC tells how ILC is seen from the history of its emergence. According to Hikmatullah, the emergence of ILC was motivated by efforts to avoid pluralism of decisions in the Religious Courts. ${ }^{1}$ Andi Herawati mentioned in his study that ILC was the result of ijtihad (independent reason) conducted by Indonesian Muslim scholars. Furthermore, according to him, ILC is the provisions of Islamic law that are adapted to the Indonesian people taken from the books of fiqh (Islamic Jurisprudence). ${ }^{2}$ Nevertheless, several legal provisions in ILC are completely new and not yet known at all in classical literature of fiqh, as explained by Intan Cahyani in his writing entitled "Pembaharuan Hukum Islam di Indonesia" (Renewal of Islamic Law in Indonesia). ${ }^{3}$

The existence of these new provisions has been a debate among Indonesian Islamic jurists and has been a hot discourse until now. One of the new provisions in KHI is Article 209 paragraph 1-2 regarding mandatory testaments for adopted children. In the tradition of the old Islamic Jurisprudence, as well as legislation in various Muslim countries, the testament must be aimed at relatives who are prevented from inheriting, such as Zaw alArham (uterine relatives), slaves and ones with different religions. Whereas in ILC the will is obligatory to address adopted children. Changes to the mandatory target of testaments from relatives to adopted children in ILC are not known with certainty of the legal basis. Whereas, each legal rule must have a clear legal basis so that the provisions can be effective and accepted in society. ${ }^{4}$

Various attempts have been made to find documents on ILC drafting activities such as archives, data materials, workshop documents, results of seminars, results of comparative studies abroad, and other data from both the Directorate General of the Religious Courts of the Indonesian Supreme Court, and from the Ministry of religion of the Republic of Indonesia as the committee in the drafting. Besides, the effort is also taken

\footnotetext{
1 Hikmatullah Hikmatullah, "Selayang Pandang Sejarah Penyusunan Kompilasi Hukum Islam Di Indonesia," Ajudikasi : Jurnal Ilmu Hukum 1, no. 2 (January 4, 2018), https://doi.org/10.30656/ajudikasi.v1i2.496.

2 Andi Herawati, "KOMPILASI HUKUM ISLAM (KHI) SEBAGAI HASIL IJTIHAD ULAMA INDONESIA," HUNAFA: Jurnal Studia Islamika 8, no. 2 (December 17, 2011): 321-40, https://doi.org/10.24239/jsi.v8i2.367.321-340.

3 Intan Cahyani, "PEMBAHARUAN HUKUM DALAM KOMPILASI HUKUM ISLAM," Al Daulah : Jurnal Hukum Pidana Dan Ketatanegaraan 5, no. 2 (December 14, 2016): 301-13, https://doi.org/10.24252/ad.v5i2.4850.

${ }^{4}$ Beni Ahmad Saebani, Fiqh Mawaris, 1st ed. (Bandung: Pustaka Setia, 2009), 61.
} 
from individuals recorded in the history of ILC drafting, but none has not produced a result. Thus, efforts to uncover the facts about ILC drafting have not been completely revealed yet to the public. Habiburrahman in his writings stated that there was a shadow drafting team playing a role in inserting several articles in the chapter of inheritance in ILC, which was considered to be contrary to Islamic law. ${ }^{5}$ Habiburrahman, furthermore, criticized the provisions. He said that the provisions of the mandatory testaments to adopted children were stowaways in ILC, inserted by the shadow team outside the team that was ratified by the Supreme Court and the Minister of Religion of Indonesia in 1985. These provisions are not based on the Koranic text but only based on the logic of customary law and merely humanitarian considerations. According to him, these provisions cannot be accepted as Islamic law due to their contrary to the Koranic texts, schools of Islamic law, and the principle of ijbari of the Islamic inheritance law. ${ }^{6}$

As a legal product, the testaments for adopted children must have a clear legal basis so that it can be accepted as a part of Islamic law and can be practiced by the community. The emergence of the refutation of legal experts on the provisions of the obligatory testaments to adopted children in ILC is an indicator or a sign that the provisions have not fully met the clear legal basis. Many people, especially legal experts doubt the validity and credibility of the regulation. They have not found a concrete explanation regarding the legal basis such as the theorem, istinbath (legal method), and beneficiary or purpose of the mandatory testaments to adopted children in ILC. The number of objections to this provision in the author's opinion is caused by an unclear and inadequate legal basis on this provision following the legal methods of Islamic law. Therefore, the author is motivated to review this provision through the 'urf approach. This method is considered quite relevant to be used as an analytical framework for the regulation of mandatory testaments to adopted children through the cultural approach of the adoption of children in Indonesia.

\section{Method}

This research is a legal normative study using conceptual and statute approaches. The primary data derive from books of Islamic Jurisprudence addressing the principle of 'urf, Islamic mandatory testaments, and Islamic Law Compilation. Those data are supported by secondary ones such as books and journal articles related to the topic.

\section{Finding and Result}

\section{The Tradition of Children Adoption in Indonesia}

Children adoption is a social reality ('urf) or social phenomena that are rife in Indonesia. Almost all regions found the practice of child adoption lasting from generation to generation until now. In fact, not only in Indonesia but also in various other countries,

\footnotetext{
${ }^{5}$ Habiburrahman, Rekonstruksi Hukum Islam Kewarisan Islam Di Indonesia, 1st ed. (Jakarta: Prenada, 2011), 132-33.

${ }^{6}$ Habiburrahman, 241.
} 
the adoption is based on legal or customary provisions in force in the country. There are various motives for adopting children, partly because they want to have children, and because they are driven by pity to help children from disadvantaged families, raising the dignity of the family, and others. ${ }^{7}$ In indigenous communities, for an adopted child, there are several terms used depending on the regions. The adopted child is usually treated like a biological child. Common terms used for adopted child are like "Anak Angkek" in Minangkabau tradition, "Anak Pupon" in Cilacap tradition, "Anak Kutut" or "Anak Pulung" in Singaraja, "Anak Akon" in Central Lombok, "Napuluku" or "Wungga" in Paniai Jayapura, "Aneuk Geutueng" in Aceh and so on. ${ }^{8}$

Adoption of children according to customary law in various regions in Indonesia has the same characteristics even though there are slightly different specifications in each region. By the characteristics of customary law, there are no strict provisions on who can adopt children, the requirements to become adoptive parents, the age limit for children to be adopted and so forth. The procedures vary according to the diversity of the local community's customary systems, but in principle, they still have a similarity. Likewise, legal consequences also vary. Some have resulted in adopted children like biological children. on the other hand, some consider adopted children only as close family members without blood ties and the right of inheritance.

In Bali, the adoption of a child is a legal act that releases the child from the relationship of his original parents and includes him into the family of his adopted father. Meanwhile, The adoption of a child in Java does not break blood relations with their biological parents. The adopted child is only put into the adoptive father's family to be taken care of and brought up, but he does not function as a biological child. But after all, the adoption of children has led to family relations between adoptive parents and adopted children in the form of rights and obligations including household assets. People of some regions in Indonesia make adoptive children as heirs who will inherit from the foster parents' assets, but most customary law areas do not place adopted children as heirs. However, they still inherit from their biological parents, as found in Goa District, Tidore Islands (Ambon), and Takengon (Central Aceh). ${ }^{9}$

Even if the adopted child does not become an heir, the child will still be given wealth through the grants. That condition is in relevance to the Eastern culture and personality saying that it is unethical if an adopted child is simply ignored without being given a grant from the foster parent's property. Unless the adopted child has betrayed the foster parents such as killing or defaming him. Then, it is only natural if he receives nothing from the foster parents and the adoption can also be canceled in that situation. ${ }^{10}$

\footnotetext{
${ }^{7}$ Muderis Zaini, Adopsi Suatu Tinjauan Dari Tiga Sistem Hukum, 5th ed. (Jakarta: Sinar Grafika, 2006), 53.

${ }^{8}$ Tolib Setiady, Intisari Hukum Adat Indonesia, 3rd ed. (Bandung: Al Fabeta, 2013), 215-16.

${ }^{9}$ Amir Mertosedono, Tanya Jawab Pengangkatan Anak Dan Masalahnya (Semarang: Dahara Prize, 2001), 14.

${ }^{10}$ Amir Mertosedono, 50-51.
} 
Thus, it can be understood that the giving property for an adopted child is part of the custom ('urf) in Indonesia. The gift can be carried out through inheritance or grants. Adoptive parents do not have the heart to ignore an adopted child without giving something from his wealth, this attitude has become part of the culture or legal awareness of society or 'urf in the archipelago.

\section{The Standing of ' $U r f$ as A Reasoning Method of Islamic Law}

Etymologically, the word "urf" means something that is known. some Arabic linguists equate 'urf with 'adat which means customs. ${ }^{11}$ According to Muhammad Abu Zahrah $^{12}$ and Wahbah Zuhaily ${ }^{13}$, 'urf in terminological meaning is something that has become a human habit in their relationships. Based on this definition, it can be understood that 'urf is community habits (customs) that are carried out continuously in daily life in the form of actions or words. Something is considered 'urf if done continuously by a community. Regarding the position of 'urf in the formation of Islamic law by Al-Qarafi, a Maliki school of scholars had forbidden the granting of a legal opinion or fatwa if the material contradicted local customs. He further asserted that the fatwa that reflects the reality of society ('urf) which has been institutionalized can undermine or breakthrough the consensus order (ijma') which has been built together by the scholars. ${ }^{14}$ In the sociology of law, it reads that law is a part of the culture of a society. The law is inseparable from the soul and the way of thinking of a society. Even the law is considered as the incarnation of the spiritual structure of a society. ${ }^{15}$

Thus, in the law formation, it is necessary to consider the legal or cultural awareness of a society where the upheld culture or values by the community are formalized into positive law. Such a law will be easier to run because long before that, the community has been able to accept the existence of these norms to be used as positive law. The standing of ' $u r f$ to be a legal basis and an appropriate order of life is based on a theorem that reads:

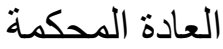

"Customary habits can be used as a legal basis". ${ }^{16}$

This rule means that a tradition or a custom of the community can be a foundation or guideline (hujjah) in establishing Islamic law for a mujtahid or judge in court, as long as there is no text in the Koran and al-Hadits that specifically regulates an issue. This means that the customs that exist in a community can be accepted and recognized by fiqh

\footnotetext{
${ }^{11}$ Amir Syarifuddin, Ushūl Fiqh II, 6th ed. (Jakarta: Logos, 2005), 364.

${ }^{12}$ Muhammad Abu Zahrah, Ushūl Fiqh, 10th ed. (Kairo: Dar al-Fikr al-Arabi, 2007), 273.

${ }^{13}$ Wahbah al-Zuhaily, Ushūl Fiqh Islamy (Damascus: Dar al-Fikr, 2006), 828.

${ }^{14}$ Abu Yazid, "Urgensi Maqashid Al-Syariah Dalam Penerapan Hukum Islam," Jurnal Istiqro' 10, no. 1 (2011): 94.

15 Soerjono Soekanto and Mustafa Abdullah, Sosiologi Hukum Dalam Masyarakat (Jakarta: Rajawali, 2000), 33.

16 Abdul Latif, Qawaid Wa Al-Dhawabizd al-Mutadhammin Li al-Taisir, Juz 1 (Madinah: Jamiah alIslamiyyah, 2003), 297.
} 
(Islamic Jurusprudence). In general, fiqh scholars practiced the method of 'urf in making the provisions of Islamic law. Hanafiyah scholars use istihsan in ijtihad (independent reasoning), and one form of that istihsan is istihsan bi al- 'urfi, i.e. istihsan that relies on 'urf. The Malikiyyah cleric made the 'urf or traditions of the people of Madinah as the basis for establishing the law and giving more priority to the 'urf than hadith al-ahad. Syafi'iyah scholars also use 'urf on problems that have no determination in the Koran and Hadith or the use of language. This school made a provision that everything that comes without any limitations in the Koran and Hadith, or the linguistic use, then returned to 'urf. ${ }^{17}$

Social reality can influence the formation or change of law as the law is built for the benefit of the community. In this context, Ibn Qayyim al-Jauziy stated that 'changes in fatwa can occur due to changes in time, place and circumstances'. However, the formation of law in the context of changes and differences in social customs cannot be applied instantly or forced. It must go through a thorough study and various considerations, and most importantly is to ensure that the law has access to apply because it needs the existence of a legal reason. ${ }^{18}$ Wahbah al-Zuhaily also stated that legal changes are required to pay attention to social customs ('urf). In case of the change of 'urf in society or an emergency arises, the law can be changed to avoid difficulties and harm as the base principle of Islamic law is to realize the convenience and reject all forms of harm and damage. ${ }^{19}$

In general, changes in the law are caused by two factors: first, because of the emergence of crime or deviations in new forms that damage the social order, disrupt the stability and comfort of people's lives. Meanwhile, no rules are governing that problem. Second, because the situation changes from one situation to another which is more conducive or conversely more severe and emergency so that it requires changes in the law to become more moderated or more stringent.

An example of a change in the law because of a change in situation is the fatwa of the contemporary generation of scholars from the Hanafi School about the permission of taking wages from teaching the Koran, becoming a prayer leader, reciting the call to prayer, and from other acts of worship. This opinion is different from the previous provisions which prohibit that. The reason is because of the changing times. Now, there is no longer found Baitul Mal institutions that play a role in funding the wages of religious teachers, prayer-caller, prayer priests and others. The prohibition of taking wages will lead to reluctance to do this work. someone will prefer other jobs such as farming, carpentry and so forth to cover their daily needs. As a result, the problem of learning the Koran, and the symbols of Islam become neglected, and no one cares. Another example is the prohibition for girls to go out in congregational prayers to the mosque due to

\footnotetext{
${ }^{17}$ Amir Syarifuddin, Ushūl Fiqh II, 375.

${ }^{18}$ Ibnu Qayyim al-Jauziyyah, 'Ilam al-Muwaqqi' in 'an Rabb al- 'Alamin, Juz 3 (Beirut: Dar al-Kutub alIlmiyah, 1991), 11.

${ }^{19}$ Wahbah al-Zuhaily, Ushūl Fiqh Islamy, 835.
} 
disturbances that endanger the safety and honor of women, especially for those who are still young girls, although previously in the time of the Prophet Muhammad, that was not prohibited. ${ }^{20}$

The position of "urf is recognized and important in the formulation of Islamic law, but that does not mean that every 'urf can be accepted as a legal basis. Only those in accordance with the provisions of the Koran and Hadith are accepted..$^{21}$ Islmic Scholars, especially Hanafi and Maliki jurists accept 'urf as a source of Islamic law with two conditions. First, "urf is not contrary to the Koran and Hadith. Second, "urf is in accordance with common sense, or in other words, 'urf does not have the potential to bring harm or injustice. ${ }^{22}$ The scholars use 'urf (customs) as an argument in two ways; first, as an argument for doing or not doing something when the sacred texts (the Koran and Hadith), on a certain matter, do not explain its provisions; second, as an argument to explain the meaning of words (lafadz) or concepts used in the sacred texts, which are inadequate if only explained or given meaning linguistically. ${ }^{23}$

Thus, the use of "urf must pay attention to the existence of the text (the Koran and Hadith). In case the text does not regulate the provision of a problem or when there is a meaning of a word (lafadz) in the text which is not understood, the 'urf can be used to establish a law for the problem and provide understanding for that word. However, if the text has established the law or provided a more detailed and accurate interpretation, then 'urf must adjust to the provisions of the text. ${ }^{24}$

\section{The Provisions of Mandatory Testaments for Adopted Children in the Perspective of 'Urf}

Although the adoption of a child does not create a blood relationship (nasab) nor cause to inherit one another, there is strong and special relationship between the child and foster parents. The relationship is in the form of a moral bond like parents and children as the adopted children are treated like their biological children in terms of nurture and affection. Because of this relationship, adoptive parents have no objections to giving wealth to their adopted children. Instead, they cannot bear to ignore an adopted child without giving anything. That legal awareness then manifests as 'urf in society. Giving wealth to adopted children when seen from the perspective of 'urf belongs to universal customs ('urf ' $\mathrm{am}$ ), that is a tradition that is found in society in general. It is not certain customs ('urf khash), that is a tradition of certain communities, at certain times and regions. ${ }^{25}$ The existence of the "urf can be used as a basis for the formation of law because

\footnotetext{
${ }^{20}$ Wahbah al-Zuhaily, 836-37.

${ }^{21}$ Ahmad Hamid, Syarah Warqat, n.d., 16.

${ }^{22}$ Al Yasa' Abubakar, Metode Istislahiah, 1st ed. (Banda Aceh: Bandar publishing, 2013), 235.

${ }^{23}$ Al Yasa' Abubakar, 235-36.

${ }^{24}$ Al Yasa' Abubakar, 246-47.

${ }^{25}$ Wahbah al-Zuhaily, al-Wajiz fi Ushül al-Fiqh, 1st ed. (Damaskus: Dar al-Fikr, 2000), 97-98.
} 
of the universality of "urf, which is comprehensively and prevalently used and applied in the community. ${ }^{26}$

In Indonesia, there are two forms of giving assets to adopted children in the 'urf of the community depending on regions and the legal system used in the practice of adoption. In some areas, especially those which are influenced by Islamic law, adopted children are given property in the form of inheritance and some other areas they are given grants in the form of wills, especially those which apply Customary law purely. In Javanese society, people who do not have children adopted other children as adopted ones. If the child behaves well toward him, he will get a part of the inheritance even in the presence of a biological child. However, the percentage of inheritance gained by adopted children is less than for biological children. Adopted children inherit from two sources: adoptive parents and their own biological parents. In Javanese language, it is usually called "ngangsu sumur loro" (inherited from two sources). ${ }^{27}$

According to the results of research from registration of customary inheritance law in the six jurisdictions of the District Court in the environment of the South, Central, and East Kalimantan High Courts, it was generally found that adopted children in Banjar society did not get inheritance because the position of adopted children was not an heir. They cannot get inheritance even in the absence of the biological child. However, with the willingness of the heirs, the adopted children can be given appropriate property. Besides, the adopted children still inherit from their biological parents. ${ }^{28}$

On the other hand, several District Court decisions in the Kalimantan region point to another fact, in which adopted children become heirs to their adoptive parents as stipulated by the Martapura District Court in Banjar Regency, South Kalimantan dated September 30, 1975 Number 15/1975 Perdata Martapura, and the Decision of the Tenggarong District Court of East Kalimantan dated January 8, 1973 Number 01/1973 Perdata Tenggarong. Furthermore, in the District Court located in Pangkalan Bun of Central Kalimantan stated that in the Dayak Ngaju tribe, adopted children can be both the heirs of their adoptive parents, and he also remains entitled to the inheritance of his biological parents. This also means that adopted children get property from two sources such as in Javanese customs. ${ }^{29}$

In the North Lampung area, adopted children inherit from their adoptive parents and excluded as heirs of their biological parents. This shows that adopted children are the heirs of adoptive parents. Meanwhile, in Gresik Regency of East Java and in Singaraja District, Garut Regency of West Java, it is determined that adopted children have the right to inherit from both adoptive parents and biological parents. However, according to most customary laws that apply in various regions in Indonesia assume that adopted children are not the heirs of adoptive parents. In Lahat Regency (Palembang), for instance, adopted

\footnotetext{
${ }^{26}$ Iman Sudiyat, Hukum Kewarisan Sketsa Asas (Yogyakarta: Liberty, 2002), 159.

${ }^{27}$ Joyodiegoeno, Asas-Asas Hukum Adat (Yogyakarta: Yayasan BP. Gajah Mada, n.d.), 75.

${ }^{28}$ Muderis Zaini, Adopsi Suatu Tinjauan Dari Tiga Sistem Hukum, 23-24.

${ }^{29}$ Muderis Zaini, 24.
} 
children only inherit if their adoption specifically states that they will inherit later from his adopted parents. Some areas in Batanghari Regency clearly state according to their customary laws that adopted children do not inherit from adoptive parents. The same thing also applies in Bontomaranu District Goa Regency Tidore Islands (Ambon), in Takengon Central Aceh District, in Cikajang District, in Garut Regency, in Sambas District West Kalimantan and several other areas. Nevertheless, adopted children can receive property from adoptive parents through a grant. Giving wealth through grants is quite common in accordance with the culture and personality of the East, for the people of Indonesia consider it very unethical that adopted child is left without being given property, except for the extraordinary things such as the betrayal of adopted children. Then, it is natural not to give property and also reasonable to cancel the status of the adopted children in that condition. ${ }^{30}$

In Acehnese, child adoption is more appropriately referred to as caregiving. In this area, adopted children are commonly called "aneuk geutueng", but in the regions of East Aceh, Langsa and Kuala Simpang, are called "anak bela". While in the Meulaboh area it is called "anak pungut". ${ }^{31}$ Adopted children are usually offspring of poor relatives, then taken to care for and nurture. Adopted children in customary law in Aceh do not inherit their adoptive parents' property, with the consideration that all the needs of adopted children have been fulfilled by adoptive parents, but they obtain property in the form of grants or testaments. ${ }^{32}$

In Bali, if a person has no descendants at all, he adopts the sons of the siblings, and so on so that only boys become heirs and everything must be based on the deliberations and consensus of the members of relatives. ${ }^{33}$ As a result of adopting children in this customary law, the child has a bond with his adoptive parents as a biological child and the relationship with the original family is cut off. ${ }^{34}$ In the Sedulur Sikep custom in Blora Regency, adopted children have the right to inherit all the inheritance of their adopted parents, especially for those who still adhere to pure customary law. As for some people who have converted to Islam in that area, their property is distributed to each of their adopted children, relatives and to public places such as mosques and Schools. ${ }^{35}$

The recognition or certainty of obtaining inheritance for adopted children from adoptive parents according to customary law is also strengthened by the decision of the Supreme Court of the Republic of Indonesia dated May 24, 1940. In this decision, adopted children according to customary law are still entitled to receive the inheritance of foster

\footnotetext{
${ }^{30}$ Muderis Zaini, 49-51.

${ }^{31}$ Bastian Tafal, Pengangkatan Anak Menurut Hukum Adat Serta Akibat-Akibat Hukumnya Di Kemudian Hari (Jakarta: Rajawali Press, 2000), 103.

32 Jhowanda Rahmat, "Kedudukan Anak Angkat Dalam Hukum Waris Adat Pada Masyarakat Aceh(Studi Kabupaten Aceh Barat)," May 3, 2010, http://repository.usu.ac.id/handle/123456789/16707.

${ }^{33}$ Hilman Hadi Kusuma, Hukum Waris Adat (Bandung: Citra Aditya Bakti, 1990), 70.

${ }^{34}$ J. Satrio, Hukum Keluarga Tentang Kedudukan Anak Dalam Undang-Undang (Bandung: Citra Aditya Bakti, 2000), 262.

${ }^{35}$ Soepomo, Bab-Bab Tentang Hukum Adat (Jakarta: Paramadina Paramita, 1993), 90.
} 
parents, but only limited to assets originating from livelihood, not inherited property. In another decision of the Supreme Court of the Republic of Indonesia dated March 18, 1959 Number 37 K / SIP / 1959 it was stated: According to customary law in force in Central Java, adopted children are only permitted to inherit joint property (gono gini). Likewise, decision No. $182 \mathrm{~K} / \mathrm{SIP} / 1959$ states: The adopted child has the right to inherit the property of his adoptive parents, but not the prior inherited property gained by the adoptive parents. ${ }^{36}$

Thus the adopted child gets the inheritance from his adoptive parents in the form of joint assets or livelihood property of his adoptive parents. Besides, it is also possible that adopted children will inherit in other ways such as grants or wills. Customary law in Indonesia is not individualistic and liberal. According to Soepomo, customary law in Indonesia has its own style, namely: first, it has a strong communal nature, meaning that humans according to customary law are creatures in close social ties. This togetherness covers the entire field of customary law. Second, It has a religious magical style related to Indonesian nature. Third, customary law is encompassed by a concrete all-around arrangement, meaning that customary law is very concerned about the number and cycle of concrete life relationships; and fourth, customary law has a visual nature, that is legal relations which are considered to only occur because they are established by a visible bond (visible signs). ${ }^{37}$

Regarding adopted children in Indonesia, even though there is a difference between one region to another in giving assets to adopted children, the similarity side also exists that each region or alliance of customary law in Indonesia generally gives assets to adopted children. The giving assets are in accordance with the Indonesian natural outlook on life saying that it is very unethical to let a foster child be left away without giving any property. So far, the provision of assets for adopted children is an 'urf that applies in society and has not been formalized as a binding rule so that in practice there is still a disparity. The property rights of adopted children should be considered in a more concrete direction, through a measurable and binding legal rule. The aim is to ensure the fulfillment of the rights of adopted children and to avoid disparities in the practice of giving property to them. Differences in community practice can be united in one pattern, namely the mandatory testaments to adopted children. The existence of the community 'urf can be used as the legal reference, but it must be ensured beforehand that the "urf is acceptable.

Amir Syarifuddin stated that there are 4 (four) requirements to accept 'urf to understand and deducing the law (istimbath). First, 'urf contains maslahah value and is accepted by common sense. Second, 'urf applies generally and equally among people in the environment or among most of its citizens. Third, 'urf, which is used as a basis in the determination of the law, has existed or been ongoing at that time, not "urf that appears later; and fourth, the 'urf does not contradict and neglect the propositions of sharia,

\footnotetext{
${ }^{36}$ Soepomo, Hukum Adat (Jakarta: Paramadina Paramita, 1999), 98.

${ }^{37}$ Soepomo, 52.
} 
especially those which are explained clearly in the Koran and Hadith. ${ }^{38}$ Based on the first condition, 'urf in the form of giving wealth to adopted children clearly has a value of a benefit (maslahah) in the form of collateral for the property. That value belongs to one of the five criteria of maslahah desired by sharia which consists of preserving religion, soul, reason, descent, and property. ${ }^{39}$ By the property, the prosperity and happiness of an adopted child's life are more secure in the future. In addition, logically the habit of giving property to adopted children can also be accepted as kindness or act that contains benefits.

In relation to the second condition, giving assets to adopted children occurs in almost all regions in Indonesia even though there are differences between one area and another in the form and amount of assets given. Thus, 'urf applies generally and evenly among the community or the majority of the community. In relation to the third condition, The use of 'urf as a legal basis is not something new but has been around for a long time and is still ongoing until now without conflict. This is because the habit of giving property to adopted children has existed long ago, along with the emergence of the practice of child adoption which continues up to now. Finally, in relation to the fouth condition. Giving wealth to an adopted child is not contrary to certain principles in Islamic law. There is no provision in the Koran and Hadith that prohibits giving property to adopted children. Likewise, Islamic scholars allow giving assets to adopted children in the form of grants or wills, but not in the form of inheritance. Yusuf Al-Qaradhawi, in this case, said that someone who adopts a child and he has no relatives, then he intends to give his property to the adopted child, he can distribute it through a grant while he is still alive, or by testaments in the limit of one-third of wealth before death. ${ }^{40}$

Based on the description above, it can be understood that the giving of assets through mandatory testaments to adopted children in the perspective of 'urf meets the requirements to be the basis for the provisions of Islamic law. The customs of giving wealth ('urf) to adopted children can be accommodated by Islamic law as an argument in solving the problem of adopted child property through the mandatory testaments. furthermore, the adopted child is entitled to receive as much as one-third of the assets left by the adoptive parents before the assets are distributed to the heirs. The mandatory wills to adopted children is a law that is pursued through rechtvinding law (istimbath) using ' urf (community legal awareness) as a basis for consideration. This legal discovery aims to address the legal problems of society by taking legal precedents that live in the community. This legal discovery is quite effective because it is in accordance with the legal doctrines that already exist in the community so that it will be more easily realized and accepted by the community. This kind of legal formation is in accordance with the mandate of Law Number 48 the Year 2009 concerning the Principles of Judicial Power as stipulated in article 5 paragraph 1 , in which judges in deciding the law must pay

\footnotetext{
${ }^{38}$ Amir Syarifuddin, Ushūl Fiqh II, 376-77.

${ }^{39}$ Said Ramadhan al-Buthī, Dhawabid al-Mașlahah fi Syari'at al-Islamiyah (Kairo: al-Muassasah alRisalah, n.d.), 241.

${ }^{40}$ Yusuf al-Qaradhawi, Halāl Wa Al-Haram Fì al-Islam (Beirut: Maktabah Wahbah, 1997), 200.
} 
attention to the legal value and sense of justice that lives in the community. On that basis, if the judge finds the legal value applied by the community, and turns out to meet a sense of justice or benefit (maslahat) for the community, the legal value can be considered as a reference in deciding laws or forming new law.

In relation to that issue, Jeremy Bentham in his utility theory argues: "the law aims to provide an advantage or benefit to society". The same objective is also found in the general principle of the fostering and establishing Islamic law, namely realizing maslahah (the benefit) for the community. ${ }^{41}$ Thus, in an effort to fulfill a sense of justice and benefit to the community, the legal provisions can adopt rules that live in a society that is considered fair and beneficial by the community itself. The formation of law regarding mandatory testaments for adopted children is considered beneficial to ensure legal certainty of the rights of adopted children's property even though in practice there are still disparities between one region and another. So far, the rights of property for the adopted children do not have definite and binding legal provisions. Adoptive parents do not have the obligation and responsibility to provide property to their adopted children. This legal uncertainty makes the rights of adopted children over their adoptive parents unguaranteed, even though the children are considered entitled to receive property because of his services to adoptive parents.

The obligatory will is a bridge to eliminate the gap between Islamic law and customary law. On one side, Islamic law forbids adopted children to inherit from adoptive parents, but on the other side, 'urf (customs) in society gives assets to adopted children in the form of grants, wills, and even inheritance. The mandatory will is an attempt to compromise between the two legal systems derived from Islamic law as a means to receive moral values behind the custom of the community to give property to adopted children. In addition, Islamic law also has an interest in controlling the community in order to run according to the provisions of sharia. Giving wealth to adopted children through inheritance is an act that violates Islamic law. So, in dealing with this reality, Islamic law must not maintain the status quo but must take concrete steps through the establishment of new laws that brings welfare and eliminate the possibility of damage in accordance with Islamic values.

In the context of legal development in Indonesia, mandatory testaments to adopted children can be one of the efforts to perfect the existing adoption rules. Law Number 23 of 2002 concerning Child Protection and Government Regulation of the Republic of Indonesia Number 54 of 2007 concerning Implementation of Child Adoption, both of these rules govern the legal procedures for adoption of children but do not regulate the property rights of adopted children from adoptive parents in a strict and certain way. So, additional rules are needed to perfect them.

\footnotetext{
${ }^{41}$ Muhammad Said al-Asymawi, Ushül Al-Syari'ah, trans. Luthfi Thomafi (Yogyakarta: LKiS, 2004), 47.
} 


\section{Conclusion}

In the customs prevailing in Indonesian society, the giving property to adopted children which have been applied for generations is in the form of grants, wills and also inheritance. The form of giving by inheritance is used in the non-muslim customary law. The custom of Indonesian society ('urf) by giving property to adopted children can be applied to Islamic law in the form of mandatory testaments because it is not contrary to Islamic law as long as done by means of grants or testaments, and not by inheriting. In this context, Islamic law and customary law are combined by taking the mandatory testaments to accommodate moral values in the social customs. The mandatory testaments become a bridge to eliminate the gap between Islamic law and customary law. On one side, Islamic law forbids adopted children to inherit from adoptive parents. On the other side, the "urf of society gives assets to adopted children in the form of grants, wills, and even inheritance. By compromising the two legal systems, mandatory testaments can be a legal solution regarding the regulation of giving property for adopted children.

\section{References}

Abdul Latif. Qawaid Wa Al-Dhawabizd al-Mutadhammin Li al-Taisir. Juz 1. Madinah: Jamiah al-Islamiyyah, 2003.

Abu Yazid. "Urgensi Maqashid Al-Syariah Dalam Penerapan Hukum Islam.” Jurnal Istiqro' 10, no. 1 (2011).

Ahmad Hamid. Syarah Warqat, n.d.

Al Yasa' Abubakar. Metode Istislahiah. 1st ed. Banda Aceh: Bandar publishing, 2013.

Amir Mertosedono. Tanya Jawab Pengangkatan Anak Dan Masalahnya. Semarang: Dahara Prize, 2001.

Amir Syarifuddin. Ushūl Fiqh II. 6th ed. Jakarta: Logos, 2005.

Bastian Tafal. Pengangkatan Anak Menurut Hukum Adat Serta Akibat-Akibat Hukumnya Di Kemudian Hari. Jakarta: Rajawali Press, 2000.

Beni Ahmad Saebani. Fiqh Mawaris. 1st ed. Bandung: Pustaka Setia, 2009.

Cahyani, Intan. "PEMBAHARUAN HUKUM DALAM KOMPILASI HUKUM ISLAM." Al Daulah: Jurnal Hukum Pidana Dan Ketatanegaraan 5, no. 2 (December 14, 2016): 301-13. https://doi.org/10.24252/ad.v5i2.4850.

Habiburrahman. Rekonstruksi Hukum Islam Kewarisan Islam Di Indonesia. 1st ed. Jakarta: Prenada, 2011.

Herawati, Andi. "KOMPILASI HUKUM ISLAM (KHI) SEBAGAI HASIL IJTIHAD ULAMA INDONESIA." HUNAFA: Jurnal Studia Islamika 8, no. 2 (December 17, 2011): 321-40. https://doi.org/10.24239/jsi.v8i2.367.321-340.

Hikmatullah, Hikmatullah. "Selayang Pandang Sejarah Penyusunan Kompilasi Hukum Islam Di Indonesia." Ajudikasi : Jurnal Ilmu Hukum 1, no. 2 (January 4, 2018). https://doi.org/10.30656/ajudikasi.v1i2.496.

Hilman Hadi Kusuma. Hukum Waris Adat. Bandung: Citra Aditya Bakti, 1990. 
Ibnu Qayyim al-Jauziyyah. 'Ilam al-Muwaqqi'in 'an Rabb al- 'Alamīn. Juz 3. Beirut: Dar al-Kutub al-Ilmiyah, 1991.

Iman Sudiyat. Hukum Kewarisan Sketsa Asas. Yogyakarta: Liberty, 2002.

J. Satrio. Hukum Keluarga Tentang Kedudukan Anak Dalam Undang-Undang. Bandung: Citra Aditya Bakti, 2000.

Joyodiegoeno. Asas-Asas Hukum Adat. Yogyakarta: Yayasan BP. Gajah Mada, n.d.

Muderis Zaini. Adopsi Suatu Tinjauan Dari Tiga Sistem Hukum. 5th ed. Jakarta: Sinar Grafika, 2006.

Muhammad Abu Zahrah. Ushül Fiqh. 10th ed. Kairo: Dar al-Fikr al-Arabi, 2007.

Muhammad Said al-Asymawi. Ushūl Al-Syari'ah. Translated by Luthfi Thomafi. Yogyakarta: LKiS, 2004.

Rahmat, Jhowanda. "Kedudukan Anak Angkat Dalam Hukum Waris Adat Pada Masyarakat Aceh(Studi Kabupaten Aceh Barat)," May 3, 2010. http://repository.usu.ac.id/handle/123456789/16707.

Said Ramadhan al-Buthī. Dhawabid al-Mașlahah fi Syari'at al-Islamiyah. Kairo: alMuassasah al-Risalah, n.d.

Soepomo. Bab-Bab Tentang Hukum Adat. Jakarta: Paramadina Paramita, 1993.

-. Hukum Adat. Jakarta: Paramadina Paramita, 1999.

Soerjono Soekanto, and Mustafa Abdullah. Sosiologi Hukum Dalam Masyarakat. Jakarta: Rajawali, 2000.

Tolib Setiady. Intisari Hukum Adat Indonesia. 3rd ed. Bandung: Al Fabeta, 2013.

Wahbah al-Zuhaily. al-Wajiz fi Ushūl al-Fiqh. 1st ed. Damaskus: Dar al-Fikr, 2000. Ushūl Fiqh Islamy. Damascus: Dar al-Fikr, 2006.

Yusuf al-Qaradhawi. Halāl Wa Al-Haram F̄̄ al-Islam. Beirut: Maktabah Wahbah, 1997. 